\title{
Nerve Growth Factor- and Neurotrophin-3-Induced Changes in Nociceptive Threshold and the Release of Substance $P$ from the Rat Isolated Spinal Cord
}

\author{
Marzia Malcangio, Neil E. Garrett, Simon Cruwys, and David R. Tomlinson \\ Department of Pharmacology, St. Bartholomew's and the Royal London School of Medicine and Dentistry, Queen Mary \\ and Westfield College, London E1 4NS, United Kingdom
}

\begin{abstract}
Acute superfusion of nerve growth factor (NGF; $1-100 \mathrm{ng} / \mathrm{ml}$ ) through a naive rat spinal cord preparation did not alter basal or electrically evoked release of substance P-like immunoreactivity (SP-LI). In contrast, neurotrophin-3 (NT-3; 1-100 ng/ml), although not modifying SP-LI basal outflow, dose-dependently inhibited the electrically evoked, but not capsaicin (10 nM)induced, release of the peptide. This NT-3 $(10 \mathrm{ng} / \mathrm{ml})$-induced inhibition persisted even in the presence of $100 \mathrm{ng} / \mathrm{ml} \mathrm{NGF}$ in the perfusion fluid and was still significant when the evoked release of SP-LI was enhanced by a prolonged in vivo treatment with NGF. Co-superfusion with naloxone $(0.1 \mu \mathrm{M})$, but not CGP $36742(100 \mu \mathrm{M})$, a GABA ${ }_{\mathrm{B}}$ antagonist, prevented NT-3 (10 ng/ $\mathrm{ml}$ ) inhibition of SP-LI release. Basal and electrically evoked release of SP-LI from the rat spinal cord in vitro was not modified $24 \mathrm{hr}$ after single systemic injection of either NGF (1 $\mathrm{mg} / \mathrm{kg})$ or NT-3 $(10 \mathrm{mg} / \mathrm{kg})$. At these time intervals from admin-
\end{abstract}

istration, NGF had induced thermal and mechanical hyperalgesia in the rat hindpaw, and NT-3 had induced mechanical, but not thermal, hypoalgesia. NT-3 administered six times over a 2 week period (at $1 \mathrm{mg} / \mathrm{kg}$ ) did not alter thermal threshold but significantly reduced electrically evoked release of SP-LI from the spinal cord. An identical treatment regimen with $1 \mathrm{mg} / \mathrm{kg}$ NGF induced a significant increase in evoked release of SP-LI. However, this was not associated with a significant hyperalgesia. Although finding that NGF-induced hyperalgesia does not clearly correlate with changes in the release of SP-LI in the spinal cord, this study shows that NT-3 is an inhibitor of SP-LI release and suggests that this mechanism may be responsible for NT-3-induced antinociception.

Key words: NGF; NT-3; hyperalgesia; hypoalgesia; substance $P$; spinal cord; adult rat; release
Nerve growth factor (NGF) and neurotrophin-3 (NT-3) belong to a family of neurotrophic factors that also includes NT-4 and -5 and brain derived neurotrophic factor (BDNF) (for review, see Ebendal, 1992). In adult rats, NGF synthesized in peripheral tissues is retrogradely transported by sensory neurons to the dorsal root ganglia (DRG) (Goedert et al., 1981). NGF binds to trkA receptors on the nerve terminals. Once in the DRG, NGF is responsible for the maintenance of expression of the nociceptive peptide substance $\mathrm{P}$ (SP) and calcitonin gene-related peptide (CGRP) (Lindsay et al., 1990). It has been recently established that the trkA receptor is expressed in unmyelinated axons derived from small cell bodies, which also express SP and CGRP (Kashiba et al., 1996). Furthermore, in the superficial dorsal horn of the rat spinal cord, trkA-like immunoreactivity has been found in lamina II (Molliver et al., 1995), which constitutes the first synapse in nociceptive pathways.

NT-3 is retrogradely transported by large, myelinated mechanoceptive and proprioceptive fibers to large-diameter cell bodies of the DRG, which do not normally contain peptides and terminate in laminae III-VI of the spinal cord (DiStefano et al., 1992;

\footnotetext{
Received April 25, 1997; revised July 30, 1997; accepted Aug. 11, 1997.

N.E.G. is supported by a grant from the British Diabetic Association to D.R.T. We thank Drs Maria de Ceballos and Paul Fernyhough for critical reading of this manuscript, Karin Fernandes and Luke Hounsom for technical assistance, Novartis (Basel, Switzerland) for the gift of CGP 36742, Genentech (South San Francisco, CA) for the gift of NGF, and Regeneron for the gift of NT-3.

Correspondence should be addressed to Dr. Marzia Malcangio, Department of Pharmacology, Queen Mary and Westfield College, Mile End Road, London E1 4NS, UK.

Copyright (C) 1997 Society for Neuroscience $0270-6474 / 97 / 178459-09 \$ 05.00 / 0$
}

Koliatsos et al., 1993). mRNA for NT-3 has been localized in rat muscle and motor neurones (Ernfors and Persson, 1991). NT-3 binding sites have been shown to be present throughout the rat spinal cord (Zhou and Rush, 1994), and immunoreactivity for the NT-3 receptor, trkC, has also been reported in the superficial dorsal horn of the monkey spinal cord (Ardvisson et al., 1994).

Systemic administration of a single dose of NGF induces mechanical and thermal hyperalgesia in adult rats, involving peripheral and central mechanisms (Lewin et al., 1993, 1994). The latter may include an enhanced release of SP within the dorsal horn of the spinal cord, which we have recently demonstrated to occur after prolonged treatment with NGF (Malcangio et al., 1997). Interestingly, it has also been shown that NT-3 infusion into the midbrain of adult rats is antinociceptive (Siuciak et al., 1994). This effect, which started $24 \mathrm{hr}$ after infusion and lasted for several days, was shown after continuous infusion of the neurotrophin into the midbrain. An involvement of the serotoninergic system has been suggested (Siuciak et al., 1994).

The aim of this study was to identify any relationship between effects of NGF or NT-3 on sensitivity to noxious stimulation and the release of the nociceptive peptide SP from the isolated spinal cord. For this purpose, the effects of single or prolonged systemic treatment with NGF or NT-3 on the threshold to noxious stimuli have been investigated. Subsequently, the spinal cords from the same animals have been isolated in vitro for the measurement of basal outflow and electrically and/or capsaicin-evoked release of sensory neuropeptides, either in the absence or presence of superfused NGF or NT-3. In a separate set of experiments the effect of acute superfusion of NGF or NT-3 on basal and elec- 
trically evoked release of SP from naive rat spinal cords has also been investigated.

\section{MATERIALS AND METHODS}

Neurotrophin administration. Adult male Wistar rats (starting weight, 250-300 gm; Charles River) were used throughout the study. For single injection studies rats received either human recombinant NGF (Genentech, South San Francisco, CA) dissolved in saline at a dose of $1 \mathrm{mg} / \mathrm{kg}$ intraperitoneally or NT-3 (Regeneron) dissolved in 0.01 м PBS, pH 7.4 (to improve stability) at doses of 1,10 , and $20 \mathrm{mg} / \mathrm{kg}$ intraperitoneally. Control rats received a single injection of saline intraperitoneally. For chronic dosing studies rats were injected subcutaneously at the back of the neck with either NGF or NT-3 at $1 \mathrm{mg} / \mathrm{kg}$ three times a week for 2 weeks. Control rats received subcutaneous saline. Animals were kept in sawdust-lined cages (three or four per cage) at an ambient temperature of $20-25^{\circ} \mathrm{C}$ under a $12 \mathrm{hr}$ light/dark cycle. Food and water were available ad libitum. Animals were quarantined for $7 \mathrm{~d}$ before any experiments were performed.

Nociceptive testing. All experiments were performed in a blind manner in which the investigator (M.M. for the plantar test and S.C. for the paw pressure test) was not aware of the injected agent. The thermal nociceptive threshold to radiant heat was quantified using the paw withdrawal test (Hargreaves et al., 1988). Briefly, rats were placed in a Perspex enclosure without restraint, and a movable infrared radiant heat source was placed directly under the plantar surface of the hindpaw (Ugo Basile). The paw withdrawal latency (PWL) to radiant heat was defined as the time from onset of the radiant heat to the withdrawal of the rat hindpaw. The radiant heat source was adjusted to result in preinjection latencies of 12-14 sec. Testing was performed at $30 \mathrm{~min}$ and 2, 4, 6, and $24 \mathrm{hr}$ after injection in acute studies and 1, 24, 48, and $72 \mathrm{hr}$ after each injection in chronic studies. Testing was alternated between hindpaws and performed at $3 \mathrm{~min}$ intervals. The average of three estimations was taken to yield a mean PWL. Before any testing was performed, rats were allowed to adjust to their environments for at least $10 \mathrm{~min}$. The mechanical nociceptive threshold was quantified using an Analgesy meter (Ugo Basile). This instrument generates a mechanical force that increases linearly with time. The force is applied directly to the dorsal surface of the rat hindpaw via a cone-shaped plunger. The nociceptive threshold is defined as the force, in grams, at which the rat attempts to withdraw its paw (cutoff force, $150 \mathrm{gm}$ ). Rats were trained by using repeated paw withdrawal tests on the previous day before experimentation. A single estimation was made for each rat at each time point. Testing was performed at $1,3,6,24$, and 48 after injection. In all cases preinjection values were subtracted from values obtained at the specified time points after NGF, NT-3, or saline administration. These differences were used for subsequent statistical analysis.

Release of endogenous substance $P$ from the dorsal horn of the rat spinal cord. Horizontal spinal cord slices were obtained from naive and saline-, NGF-, or NT-3-treated rats, as described previously (Malcangio and Bowery, 1993, 1994, 1996b). Hemisected dorsal lumbosacral slices (350$400 \mu \mathrm{m}$ thick to ensure adequate oxygenation) with L4 and L5 dorsal roots attached were isolated and mounted in a three-compartment bath. The slice $(0.5 \mathrm{~cm}$ long) was continuously superfused with oxygenated $\left(95 \% \mathrm{O}_{2}\right.$ and $\left.5 \% \mathrm{CO}_{2}\right)$ Krebs' solution (in mM: $\mathrm{NaCl}, 118 ; \mathrm{KCl}, 4$; $\mathrm{MgSO}_{4}, 1.2 ; \mathrm{KH}_{2} \mathrm{PO}_{4}, 1.2 ; \mathrm{NaHCO}_{3}, 25 ; \mathrm{CaCl}_{2}, 2.5$; and glucose, 11) at $1 \mathrm{ml} / \mathrm{min}$ at room temperature. Although spinal cord slices have been kept alive for as long as $50 \mathrm{hr}$ at $18-20^{\circ} \mathrm{C}$ (Kerkut and Bagust, 1995), it has been recently reported that CGRP release from spinal cord prisms induced by either capsaicin or potassium ions was higher at $40^{\circ} \mathrm{C}$ than at $20^{\circ} \mathrm{C}$ (Dirig et al., 1997). However, our conditions (room temperature) were chosen to obtain a submaximal increase in peptide content in the stimulated fraction, which could be pharmacologically manipulated. The flow rate of superfusing solution is crucial to avoid any risk of hypoxic damage for the nerve cells in the inner region of the slice. Rates of 0.5-2 $\mathrm{ml} / \mathrm{min}$ have been successfully used for release experiments (Kangrga and Randic, 1990; Andreeva and Rang, 1993; Malcangio and Bowery, 1993). The dorsal roots were sealed across a leak-proof partition of high-vacuum grease (Dow Corning Corp., Midland, MI) into the lateral compartments. On each side two lumbar roots were draped on pairs of bipolar platinum electrodes and compartments filled with mineral oil to avoid dehydration (Aldrich, Milwaukee, WI). After $1 \mathrm{hr}$ equilibration, normal Krebs' solution was substituted with modified Krebs' solution containing $0.1 \%$ bovine serum albumin (BSA; Sigma, Poole, UK), 100 $\mu \mathrm{M}$ captopril (Sigma), $1 \mu \mathrm{M}$ phosphoramidon (Sigma), $20 \mu \mathrm{g} / \mathrm{ml}$ bacitracin (Sigma), and $6 \mu \mathrm{M}$ dithiothreitol (Sigma). The presence of protease inhibitors and antioxidant was essential for determining basal outflow of substance P-like immunoreactivity (SP-LI), which appears to vary between preparations. After 16 min, samples of superfusates were collected ( 8 min collection time) in acetic acid $(0.1 \mathrm{~N})$ before, during, and after stimulation of the dorsal roots and/or superfusion of drugs. The stimulation parameters used to examine the electrically evoked release of SP-LI were $20 \mathrm{~V}, 0.5 \mathrm{msec}$ at $1 \mathrm{~Hz}$ for $8 \mathrm{~min}$, and the stimulating current was $12.3 \pm 1.3 \mathrm{~mA}$. The voltage dependency of SP-LI release in this preparation has been established previously, and, as expected, at voltages of $<10 \mathrm{~V}$ at which $\mathrm{C}$ fibers are not likely to be activated (Kangrga and Randic, 1991), no significant release of SP-LI was observed (Malcangio and Bowery, 1993). Furthermore, the $80 \%$ reduction in evoked release of SP-LI from spinal cord of rats neonatally treated with capsaicin suggested that unmyelinated fibers were the major source of this peptide in this preparation (Teoh et al., 1996).

Acute superfusion of neurotrophins. Modified Krebs' solution was used to dilute NGF stock solution $(4.69 \mathrm{mg} / \mathrm{ml}$ in saline) and to dissolve NT-3. Superfusates were collected in the following order to evaluate the effect of acute superfusion: two fractions to measure basal outflow of SP-LI, one fraction in the absence (control) or presence of $\mathrm{NGF}$ and/or NT-3, one fraction in the presence or absence (control) of neurotrophins to measure electrically evoked release of SP-LI, and three fractions to measure the return to basal levels. When spinal cords from rats treated chronically with either NGF or NT-3 were used, fractions were collected in the following order; three fractions to measure basal outflow, one fraction to assess electrically evoked release of SP-LI, and three fractions to assess recovery to basal values. In some experiments, two more fractions were collected to measure capsaicin-induced release of SP-LI and CGRP-LI. Capsaicin $(1 \mu \mathrm{M})$ was superfused for the initial 2 min of the first fraction. In previous studies this concentration of capsaicin was able to induce a sixfold increase in SP-LI content, although the dorsal roots had been electrically stimulated previously (Malcangio and Bowery, 1993), suggesting that capsaicin-sensitive pools were still available for releasing SP-LI. In contrast, electrical stimulation of the dorsal roots was not effective after capsaicin superfusion, indicating that these SP-LI pools were the same activated by capsaicin (M. Malcangio, unpublished data).

In another set of experiments SP-LI release from isolated spinal cords was induced by superfusing capsaicin $(1 \mathrm{nM}-1 \mu \mathrm{M})$ for the initial 2 min of an $8 \mathrm{~min}$ fraction at $1 \mathrm{ml} / \mathrm{min}$. The effect of co-superfusion of NT-3 (100 $\mathrm{ng} / \mathrm{ml})$ on capsaicin $(10 \mathrm{~nm})$-induced release of SP-LI was then evaluated. Eight min superfusates ( $8 \mathrm{ml}$ volume) were collected in the following order: two fractions to measure basal outflow of SP-LI, one fraction in the absence (control) or presence of NT-3, one fraction with or without (control) NT-3 in the presence of capsaicin for the initial $2 \mathrm{~min}$, and three fractions to measure the return to basal levels.

At the completion of some experiments the spinal cord slice was blotted and weighed, and SP-LI and CGRP-LI were extracted. The tissue was immersed in glacial acetic acid for $1 \mathrm{hr}$, heated in a boiling water bath for $15 \mathrm{~min}$, homogenized, and centrifuged (12,000 rpm for $20 \mathrm{~min}$ ), and the supernatant was collected.

Extraction and assay of SP-LI and CGRP-LI. Samples were partially purified and desalted by using $100 \mathrm{mg}$ Sep-Pak $\mathrm{C}_{18}$ reverse-phase silica gel cartridges (Waters Associates, Watford, UK). Cartridges were first washed with $5 \mathrm{ml}$ of acetonitrile (100\%; HPLC grade; BDH Chemicals, Poole, UK) followed by $2 \mathrm{ml}$ of trifluoroacetic acid $0.1 \%$ (TFA; HPLC grade; $\mathrm{BDH})$. Samples were then loaded into the column followed by 3 $\mathrm{ml}$ of TFA. Peptides were eluted using $2 \mathrm{ml}$ of $80 \%$ acetonitrile in $0.1 \%$ TFA (recovery, 90\%). The eluates were dried by evaporation at $55^{\circ} \mathrm{C}$ under nitrogen and stored at $-70^{\circ} \mathrm{C}$ until they could be assayed for SP-LI or CGRP-LI content by radioimmunoassay $(1 \mathrm{fmol} /$ tube sensitivity for both peptides) using the scintillation proximity technique (Amersham, Buckinghamshire, UK) as described previously (Malcangio and Bowery, 1993, 1996b; Malcangio et al., 1997). Rabbit antiserum against SP was most reactive with the whole SP undecapeptide but showed no reaction with N-terminal fragments and neurokinin A or B (Amersham). Antiserum against CGRP was specific for rat, showing only $35 \%$ crossreactivity with human CGRP (Peninsula Laboratories, Belmont, CA).

Data calculation and statistical analysis. The data are presented as mean \pm SEM. ANOVA, Mann-Whitney $U$ test, and Student's $t$ test were used when appropriate. In Figures 3 and 4, areas under the curves were calculated, and means were compared by Student's $t$ test. 


\section{RESULTS}

\section{Effect of in vitro spinal cord superfusion with NGF and NT-3 on SP-LI release}

Because both trkA and trkC receptors have been reported to be present in the dorsal horn of the spinal cord (see the introductory remarks), the effect of their activation on SP-LI release has been investigated by slice superfusion with NGF and NT-3. When control slices were mounted, electrical stimulation of attached dorsal roots caused a significant increase in SP-LI content in the superfusates (fourth and fifth fractions) over the peptide basal outflow (initial three fractions) (Fig. $1 A$ ). The presence of NT-3 $(100 \mathrm{ng} / \mathrm{ml})$ in the superfusion fluid, one fraction before and during stimulation of the dorsal roots (third and fourth fractions) (Fig. 1A), significantly inhibited the evoked SP-LI release (fourth fraction) without changing the basal outflow (third vs first and second fractions) (Fig. $1 A)$. The effect of NT-3 $(1-100 \mathrm{ng} / \mathrm{ml})$ was concentration-dependent (Fig. 1B). Addition of NT-3 (100 ng/ $\mathrm{ml})$ to the electrically stimulated fraction after collection did not modify SP-LI content, excluding that specific binding of the neurotrophin to the released SP could be responsible for the observed inhibition (data not shown). Superfusion of spinal cord slices with NGF (1-100 ng/ml) did not modify either electrically evoked release of SP-LI (Fig. 1C) or basal outflow of the peptide (see legend to Fig. 1C).

To assess the selectivity of NT-3 effect on electrically evoked release of SP-LI, which is likely to be dependent on activation of voltage-sensitive calcium channels (VSCCs), SP-LI release was also induced by capsaicin superfusion through the isolated spinal cord. Capsaicin action seems not to be mediated by activation of VSCCs, and it is blocked by the inorganic dye ruthenium red (for review, see Maggi, 1991). After a 2 min capsaicin superfusion (1 $\mathrm{nM}-1 \mu \mathrm{M})$ the peptide content in the superfusate was increased over basal content $(7.3 \pm 1.1 \mathrm{fmol} / 8 \mathrm{ml}$ fraction; $n=22)$ by $62.5 \pm$ $10.6 \mathrm{fmol} / 8 \mathrm{ml}$ fraction at $1 \mu \mathrm{M}(n=6 ; p<0.001), 44.2 \pm 5.0$ $\mathrm{fmol} / 8 \mathrm{ml}$ fraction at $100 \mathrm{~nm}(n=3 ; p<0.001), 13.5 \pm 2.6 \mathrm{fmol} / 8$ $\mathrm{ml}$ fraction at $10 \mathrm{nM}(n=4 ; p<0.05)$, and $4.65 \pm 1.0 \mathrm{fmol} / 8 \mathrm{ml}$ fraction at $1 \mathrm{nM}(n=3$; n.s.). The presence of NT-3 $(100 \mathrm{ng} / \mathrm{ml})$ in one fraction before capsaicin and in the whole fraction in which capsaicin $(10 \mathrm{~nm})$ was only superf used for the initial $2 \mathrm{~min}$ did not reduce SP-LI release (fmol $/ 8 \mathrm{ml}$ fraction; $n=10.4 \pm 1.0 ; n=6$ ).

These data indicate that activation of $t r k \mathrm{C}$, but not $t r k \mathrm{~A}$ receptor in the dorsal horn of the spinal cord, can selectively modulate the electrically evoked release of SP-LI.

\section{Effect of NGF on NT-3-induced inhibition of SP-LI release from the spinal cord}

To ascertain whether activation of trkA receptor could modify NT-3-induced inhibition of evoked release of SP-LI, NGF (100 $\mathrm{ng} / \mathrm{ml})$ was co-superfused with NT-3 (10 ng/ml) before and during stimulation of the dorsal roots. The presence of NGF in the superfusion fluid did not prevent the NT-3 effect (Fig. 2A). To increase the amount of SP-LI, which could be released after electrical stimulation of the dorsal roots, rats were treated with six injections of NGF ( $1 \mathrm{mg} / \mathrm{kg})$ over 2 weeks, and $24 \mathrm{hr}$ after the last injection their spinal cords were isolated in vitro. SP-LI release was doubled in NGF-treated spinal cords compared with controls (Fig. 2B). Basal outflow of the peptide was also increased (see legend to Fig. $2 B$ ). Interestingly, acute NT-3 (10 ng/ml) superfusion through spinal cord slices obtained from NGF-treated rats inhibited the NGF-induced increase in evoked SP-LI (Fig. 2B).

These data indicate that NT-3 is not likely to exert its effect on
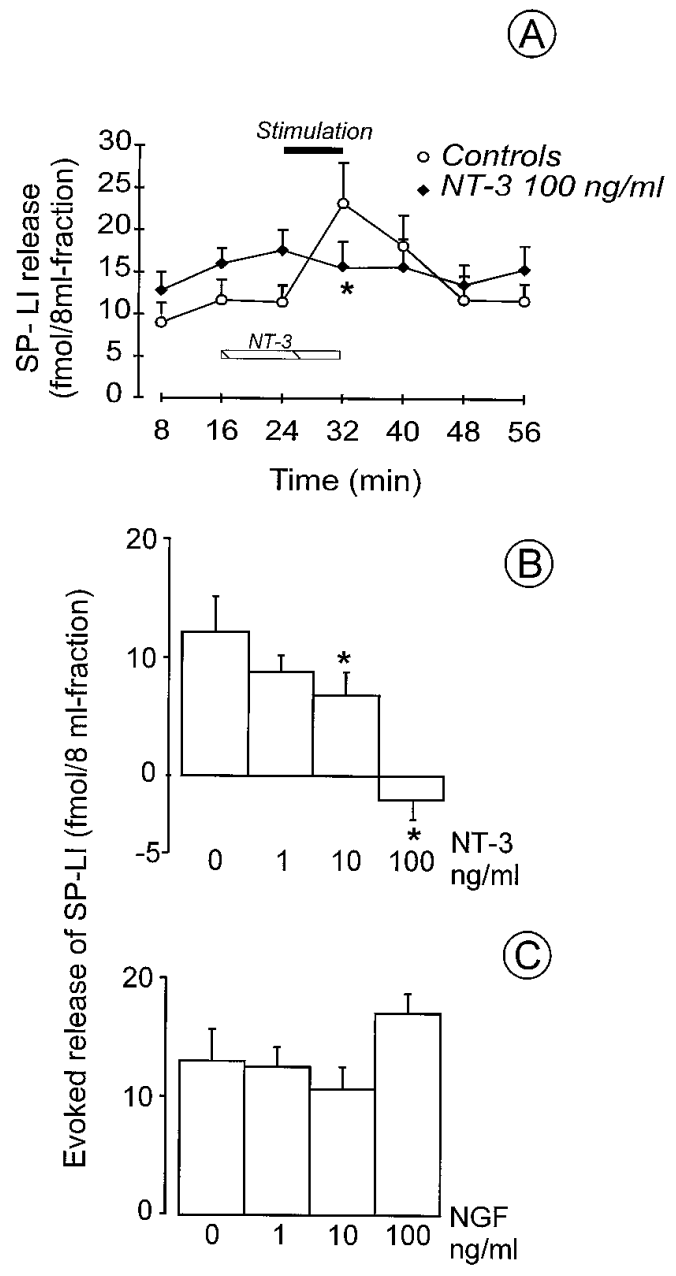

Figure 1. A, Effect of NT-3 superfusion on electrically evoked SP-LI release from the rat spinal cord in vitro. NT-3 $(n=6)$ was present in the $8 \mathrm{~min}$ fraction before stimulation and during $8 \mathrm{~min}$ stimulation of dorsal roots $(20 \mathrm{~V}, 0.5 \mathrm{msec}$ at $1 \mathrm{~Hz}$, horizontal black bar). Eight preparations were used as controls. $B, \mathrm{NT}-3$ dose-response effect on the release of SP-LI. NT-3 (1-100 ng/ml) was superfused in the $8 \mathrm{~min}$ fraction before and during $8 \mathrm{~min}$ stimulation. Values were obtained from at least five preparations and are expressed as femtomoles present in the stimulated fraction after subtraction of the basal outflow: $10.7 \pm 0.86 \mathrm{fmol} / 8 \mathrm{ml}$ fraction in controls $(n=8)$ (mean value of the first three collected fractions); $14.4 \pm 2.0 \mathrm{fmol} / 8 \mathrm{ml}$ fraction in the first two fractions collected before NT-3; and $17.6 \pm 2.4 \mathrm{fmol} / 8 \mathrm{ml}$ fraction in the fraction collected in the presence of NT-3 $(100 \mathrm{ng} / \mathrm{ml})(n=6) .{ }^{*} p<0.05$ versus controls, Mann-Whitney $U$ test. $C$, Effect of topical application of NGF on the release of SP-LI from the rat spinal cord in vitro. NGF $(1-100 \mathrm{ng} / \mathrm{ml})$ was superfused in the $8 \mathrm{~min}$ fraction before stimulation and during $8 \mathrm{~min}$ stimulation of the dorsal roots. Values were obtained from at least three preparations and are expressed as femtomoles present in the stimulated fraction after subtraction of the basal outflow: $13.8 \pm 1.8 \mathrm{fmol} / 8 \mathrm{ml}$ fraction in controls $(n=3)$; and $14.6 \pm 4.5 \mathrm{fmol} / 8 \mathrm{ml}$ fraction in NGF $(100$ $\mathrm{ng} / \mathrm{ml})(n=6)$.

SP-LI release through an activation of the trkA receptor, which has been localized on SP-containing terminals (Kashiba et al., 1996).

\section{Effect of CGP 36742 and naloxone on NT-3 induced inhibition of SP-LI from the spinal cord}

To reverse NT-3 action, antagonists at receptors of two major inhibitory systems in the spinal cord, the $\mathrm{GABA}_{\mathrm{B}}$ ergic and opioid systems, which are known to modulate SP release negatively (Go and Yaksh, 1987; Malcangio and Bowey, 1993), have been used. 


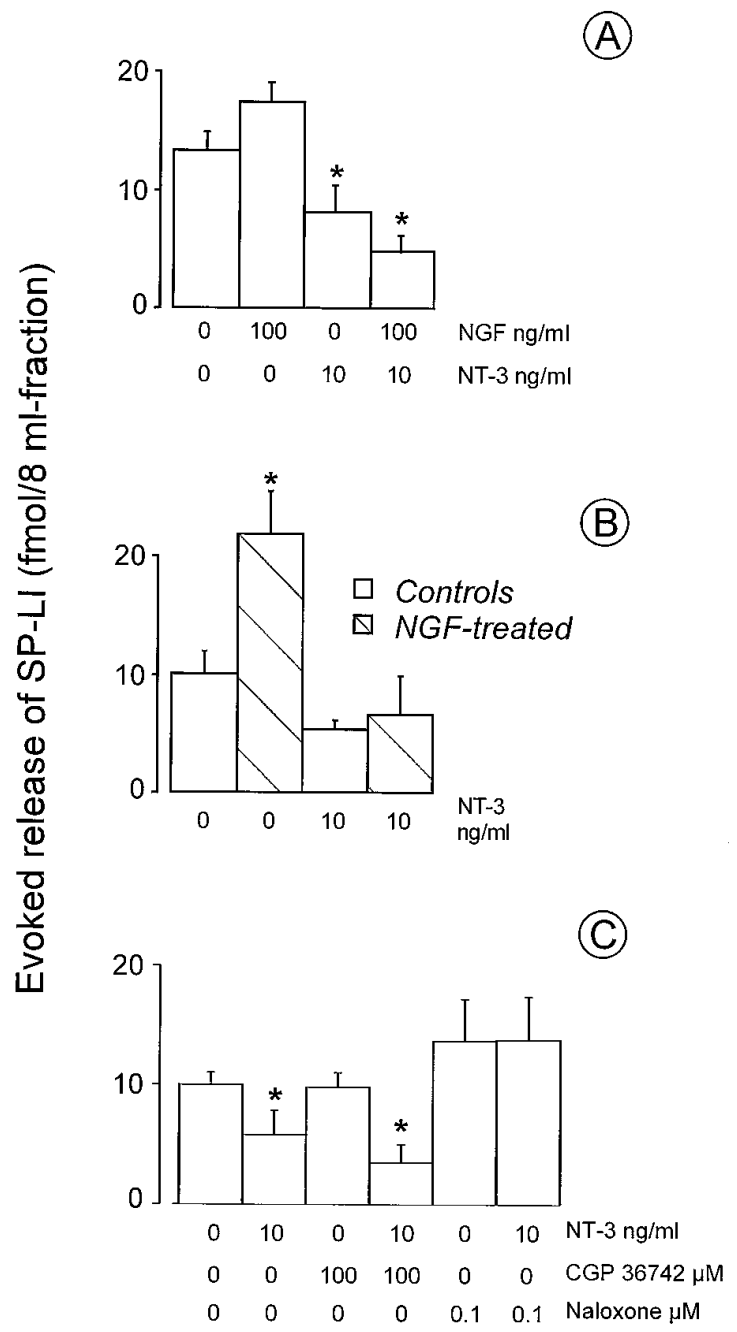

Figure 2. A, Effect of superfusion of NGF (100 ng/ml) and NT-3 (10 $\mathrm{ng} / \mathrm{ml}$ ) separately or in combination on SP-LI release from the spinal cord. NGF and NT-3 were present in the $8 \mathrm{~min}$ fraction before stimulation and during 8 min stimulation of the dorsal roots. Values were obtained from three to six preparations and are expressed as femtomoles of SP-LI present in the stimulated fraction after subtraction of the basal outflow: $11.7 \pm 0.8 \mathrm{fmol} / 8 \mathrm{ml}$ fraction in controls $(n=$ $4) ; 10.5 \pm 2.1 \mathrm{fmol} / 8 \mathrm{ml}$ fraction in NGF $(100 \mathrm{ng} / \mathrm{ml})(n=5) ; 11.3 \pm$ $1.7 \mathrm{fmol} / 8 \mathrm{ml}$ fraction after NT-3 $(10 \mathrm{ng} / \mathrm{ml})(n=3)$; and $11.5 \pm 1.3$ $\mathrm{fmol} / 8 \mathrm{ml}$ fraction after NT-3 and NGF $(n=5) . B$, Effect of topical application of NT-3 $(10 \mathrm{ng} / \mathrm{ml})$ on electrically evoked release of SP-LI from the spinal cord of rats previously injected with either saline or NGF $(1 \mathrm{mg} / \mathrm{kg}$, s.c., 3 times a week for 2 weeks). Dorsal roots were electrically stimulated for $8 \mathrm{~min}$. Values were obtained from at least five preparations and are expressed as femtomoles of SP-LI present in the stimulated fraction after subtraction of the basal outflow: $6.4 \pm 0.5$ $\mathrm{fmol} / 8 \mathrm{ml}$ fraction in controls $(n=5) ; 10.3 \pm 1.7 \mathrm{fmol} / 8 \mathrm{ml}$ fraction in NGF-treated rats $(n=4) ; 6.6 \pm 0.2 \mathrm{fmol} / 8 \mathrm{ml}$ fraction $(n=5)$ in NT-3 alone; $10.8 \pm 1.5 \mathrm{fmol} / 8 \mathrm{ml}$ fraction $(n=5)$ after NGF and NT-3. ${ }^{*} p<$ 0.05 , Mann-Whitney $U$ test versus each of three groups. $C$, Effect of co-superfusion with NT-3 $(10 \mathrm{ng} / \mathrm{ml})$ of CGP $36742(100 \mu \mathrm{M})$ or naloxone $(0.1 \mu \mathrm{M})$ on SP-LI release from the spinal cord. Drugs were present in the $8 \mathrm{~min}$ fraction before stimulation and during $8 \mathrm{~min}$ stimulation. Values were obtained from a total of 22 preparations and are expressed as femtomoles present in the stimulated fraction after subtraction of the basal outflow SP-LI, which was $11.2 \pm 2.3 \mathrm{fmol} / 8 \mathrm{ml}$ fraction $(n=22)$ and was modified by neither CGP 36742 nor naloxone. ${ }^{*} p<0.05$ versus controls, Mann-Whitney $U$ test.

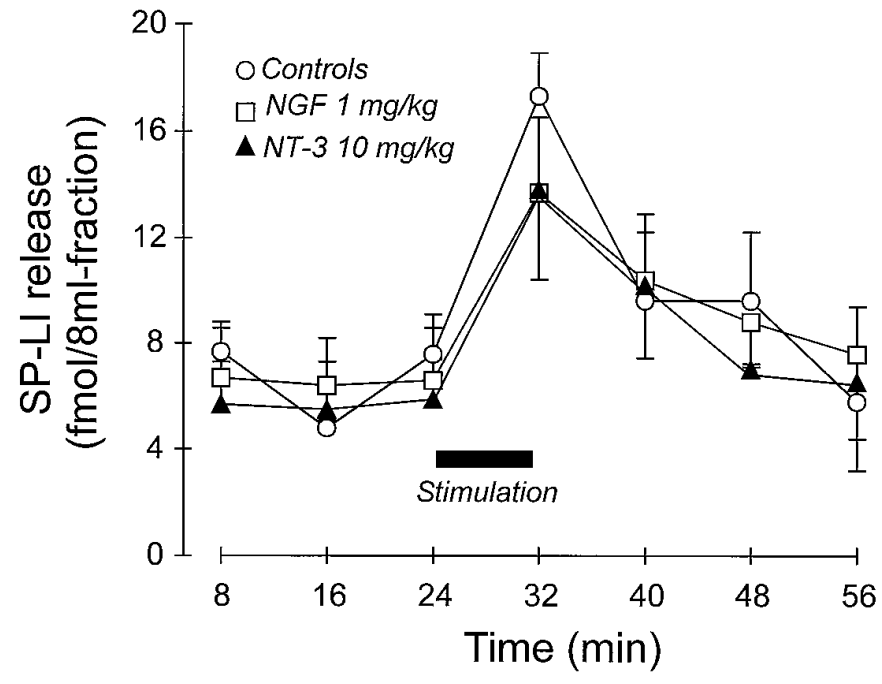

Figure 3. Effect of single administration of saline $(n=5)$, NGF $(n=3)$, or NT-3 $(n=4)$ on the release of SP-LI from the rat spinal cord in vitro. Spinal cords were isolated $24 \mathrm{hr}$ after injections. SP-LI release was induced by electrical stimulation of the dorsal roots for 8 min. Stimulusevoked release (area under the curve) was not significantly different for the three treatments.

The $\mathrm{GABA}_{\mathrm{B}}$ antagonist 3-aminopropyl- $n$-butyl phosphinic acid $(100 \mu \mathrm{M})$ co-superfused with NT-3 $(10 \mathrm{ng} / \mathrm{ml})$ did not change NT-3-induced inhibition of evoked SP-LI release from naive rat spinal cord (Fig. 2C). This concentration of the antagonist, which did not alter evoked SP-LI release, has been previously shown to be effective in preventing the inhibition of evoked SP-LI release induced by the $\mathrm{GABA}_{\mathrm{B}}$ agonist baclofen (Malcangio and Bowery, 1993). However, the $\mathrm{GABA}_{B}$ ergic system appears to be activated in situations such as chronic inflammatory pain to counteract the enhanced release of SP in the spinal cord (for review, see Malcangio and Bowery, 1996a). Thus, it is not surprising that a $\mathrm{GABA}_{\mathrm{B}}$ receptor antagonist did not modify the effect of NT-3 in normal rat spinal cord. In contrast, the opioid antagonist naloxone $(0.1 \mu \mathrm{M})$, at a concentration that was without effect on evoked SP-LI release, prevented NT-3-induced inhibition of the release of this peptide (Fig. $2 C$ ).

These data indicate that NT-3-induced inhibition of evoked release of SP-LI is reversible by naloxone but not by a $\mathrm{GABA}_{\mathrm{B}}$ receptor antagonist.

The subsequent aim was to evaluate whether these in vitro observations could be confirmed by in vivo experiments in which NT-3 was systemically injected and the spinal cords were isolated $24 \mathrm{hr}$ after either single or prolonged administration.

\section{Effect of single systemic injection of NGF and NT-3 on SP-LI release from the spinal cord in vitro}

Administration of a single systemic dose of NGF $(1 \mathrm{mg} / \mathrm{kg})$ or NT-3 $(10 \mathrm{mg} / \mathrm{kg})$ induced no change in either basal outflow or electrically evoked release of SP-LI from the spinal cord removed and studied $24 \mathrm{hr}$ after injection (Fig. 3). At this time interval after administration, NGF-treated rats had developed both thermal and mechanical hyperalgesia, and NT-3 rats had developed mechanical, but not thermal, hypoalgesia (see subsequent sections).

\section{Effect of prolonged treatment with NT-3 on the release of SP-LI from isolated spinal cords}

Prolonged treatment of rats with NT-3 (1 mg/kg, s.c., each dose; six doses over 2 weeks) inhibited the electrically evoked release of 


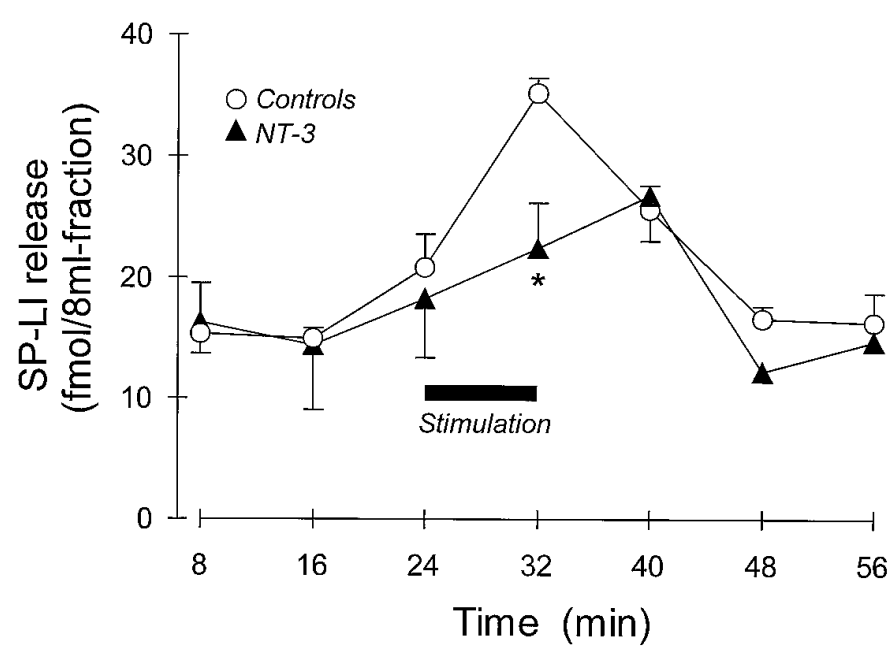

Figure 4. Effect of prolonged administration of either saline $(n=5)$ or NT-3 ( $1 \mathrm{mg} / \mathrm{kg}$, s.c., 3 times a week for 2 weeks; $n=7)$ on SP-LI release from the rat spinal cord in vitro. SP-LI release was evoked by electrical stimulation of the dorsal roots for $8 \mathrm{~min}$ (horizontal black bar) of spinal cord preparation isolated $24 \mathrm{hr}$ after last injection of NT-3. ${ }^{*} p<0.05$, Student's $t$ test between femtomoles of SP-LI present in the stimulated fraction after subtraction of the basal outflow of control and NT-3-treated spinal cords (see Results). The areas under curves were not significantly different.

SP-LI (in fmol/8 ml fraction: controls, $18.2 \pm 1.3 ; \mathrm{NT}-3,10.7 \pm$ $1.9 ; p<0.05$; see Fig. 4) without changing the basal outflow of the peptide. Capsaicin-induced release of SP-LI and CGRP-LI was not significantly changed in NT-3-treated spinal cords compared with controls (Table 1). The total content of both peptides in the dorsal horn slices was not significantly reduced in NT-3-treated compared with saline-treated rat spinal cords (Table 1).

\section{Effect of a single administration of NGF or NT-3 on rat thermal and mechanical thresholds}

In an attempt to correlate the observed effects of NGF and NT-3 on the release of the nociceptive peptide SP, with potential changes in nociceptive sensitivity, the effect of single or prolonged administration of the neurotrophins on thermal and mechanical thresholds were evaluated. In the plantar test, the overall mean preinjection PWL values to noxious heat stimuli were $12.9 \pm 0.68 \mathrm{sec}(n=32)$. For each rat, preinjection PWLs were subtracted from PWL values obtained at various intervals after the administration of NGF or NT-3, and the differences are reported in Figure $5 A$. The injection of saline induced only minor numerical changes in PWL values, none of which were significant, at $30 \mathrm{~min}$ and 2, 4, 6, and $24 \mathrm{hr}$ time intervals (see Fig. 5A). A single systemic injection of NGF $(1 \mathrm{mg} / \mathrm{kg})$ induced a significant decrease $(p<0.05)$ in PWL scores (compared with controls) as early as $30 \mathrm{~min}$ after injection. The effect was still significant $(p<$ $0.05) 24 \mathrm{hr}$ after injection (Fig. 5A). Systemic administration of NT-3 (1 mg/kg) significantly reduced PWL $30 \mathrm{~min}$ after injection. Thereafter, no change in PWL was observed at time intervals up to $24 \mathrm{hr}$ after injection (Fig. 5A). Administration of a higher dose of NT-3 $(10 \mathrm{mg} / \mathrm{kg})$ did not alter the rat thermal threshold (data not shown). Co-administration of NGF and NT-3 reduced PWL scores to the same extent as NGF alone at $30 \mathrm{~min}$ and 2, 4, and $24 \mathrm{hr}$ after injection (Fig. 5A). However, at the $6 \mathrm{hr}$ time point, co-administration of the two neurotrophins reduced PWL scores significantly more than NGF alone (Fig. $5 A$ ).

In the paw pressure test, the overall mean preinjection thresh- olds to noxious mechanical stimuli were $74.0 \pm 0.7 \mathrm{gm}(n=30)$. For each rat, preinjection paw pressure thresholds were subtracted from thresholds obtained at various intervals after the neurotrophin injections, and the differences are reported in Figure $5 B$. Single systemic administration of NGF $(1 \mathrm{mg} / \mathrm{kg})$ significantly reduced $(p<0.05)$ paw pressure threshold, but only $24 \mathrm{hr}$ after injection. The effect was still significant $(p<0.05) 48 \mathrm{hr}$ after injection (Fig. 5B). NT-3 injection at $1 \mathrm{mg} / \mathrm{kg}$ caused a decrease in paw pressure threshold $6 \mathrm{hr}$ after injection; at 10 and $20 \mathrm{mg} / \mathrm{kg}$ NT-3 caused a decrease in paw pressure threshold 1 and $6 \mathrm{hr}$ after injection (Fig. 5B). Then a significant increase in mechanical threshold was detected $24 \mathrm{hr}$ after injection of 10 and $20 \mathrm{mg} / \mathrm{kg} \mathrm{NT}-3$. These effects were absent in tests made at $48 \mathrm{hr}$ after injection.

\section{Effect of prolonged treatment with NGF and NT-3 on rat threshold to thermal stimulation}

The first of six injections of NGF to rats $(1 \mathrm{mg} / \mathrm{kg})$ induced a significant decrease $(p<0.05)$ in PWL compared with salinetreated rats at 1 and $24 \mathrm{hr}$ time intervals (see Fig. 6A, $B$, respectively). The hyperalgesia that developed $1 \mathrm{hr}$ after the first injection of NGF persisted at this $1 \mathrm{hr}$ interval after each of the following four injections of NGF and disappeared after the sixth injection (Fig. 6A). A tendency to a decreased threshold compared with controls was observed at the $24 \mathrm{hr}$ intervals in rats repeatedly treated with NGF (Fig. 6B). However, this effect never reached statistical significance until $24 \mathrm{hr}$ after the last (sixth) injection, when a significant decrease $(p<0.05)$ in PWL compared with controls was observed (Fig. $6 B$ ). It is worth noting that 30 min after the second injection of NGF, rats presented a typical immunological reaction, showing swollen noses and paws, red ears, and redness at the tip of the tail. These effects were less marked after the third injection and did not show afterward.

Prolonged administration of NT-3 to rats $(1 \mathrm{mg} / \mathrm{kg})$ did not modify the threshold to thermal noxious stimulation. In controls $(n=9)$ PWL was $13.3 \pm 1.6 \mathrm{sec}$ before injections began and $12.2 \pm 0.8 \mathrm{sec}$ after 2 weeks of saline injections; in the NT-3 group $(n=9)$ PWL was $11.7 \pm 0.4$ before treatment and $10.5 \pm$ $0.6 \mathrm{sec}$ after 2 weeks of NT-3 treatment. No effects on behavior and no immunological responses were noted. After either single or prolonged administration of NT-3 the body weight of the treated animals increased at the same rate as the controls over the course of the experiment. There was no apparent muscle tone weakness or motor dysfunction assessed by general observation. The general exploratory behavior of the rats on removal from the cages was unchanged.

\section{DISCUSSION}

\section{NGF-induced changes in pain threshold and release of SP-LI from the spinal cord}

This study confirms that single systemic administration of NGF to the rat induces thermal and mechanical hyperalgesia (Lewin et al., 1993). Thermal hyperalgesia developed as soon as $30 \mathrm{~min}$ after injection (early component) and persisted for up to $24 \mathrm{hr}$ (late component), whereas mechanical hyperalgesia started $24 \mathrm{hr}$ after injection and persisted for up to $48 \mathrm{hr}$. After these acute changes, prolonged administration of NGF is associated with a return to normal thermal nociceptive sensitivity. We also showed that, in contrast to NGF, a single systemic administration of NT-3, although not affecting thermal threshold, induced significant mechanical hypoalgesia $24 \mathrm{hr}$ after administration. Single 
Table 1. Effect of prolonged treatment with NT-3 (1 mg/kg, s.c., three times a week for 2 weeks) on capsaicin-induced SP-LI and CGRP-LI release and on peptide total content in the spinal cord preparation

\begin{tabular}{lllll} 
Treatment & $n$ & $\begin{array}{l}\text { Capsaicin-induced } \\
\text { release of SP-LI } \\
(\mathrm{fmol} / \mathrm{ml})\end{array}$ & $\begin{array}{l}\text { Capsaicin-induced } \\
\text { release of CGRP-LI } \\
(\mathrm{fmol} / \mathrm{ml})\end{array}$ & $\begin{array}{l}\text { CGRP-LI total content } \\
\text { (fmol/mg tissue) }\end{array}$ \\
\hline Saline & 5 & $10.0 \pm 1.9$ & $20.9 \pm 4.7$ & $94.3 \pm 26.8$ \\
NT-3 & 7 & $8.3 \pm 2.6$ & $15.8 \pm 6.2$ & $77.3 \pm 18.5$ \\
\hline
\end{tabular}

Capsaicin $(1 \mu \mathrm{M})$ was superfused for $2 \mathrm{~min}$ of $16 \mathrm{~min}$ collection of $16 \mathrm{ml}$ perfusates. To determine the peptide total contents, each slice was extracted in glacial acetic acid (see Materials and Methods). The tissue weights were $30 \pm 3.5 \mathrm{mg}(n=12)$.
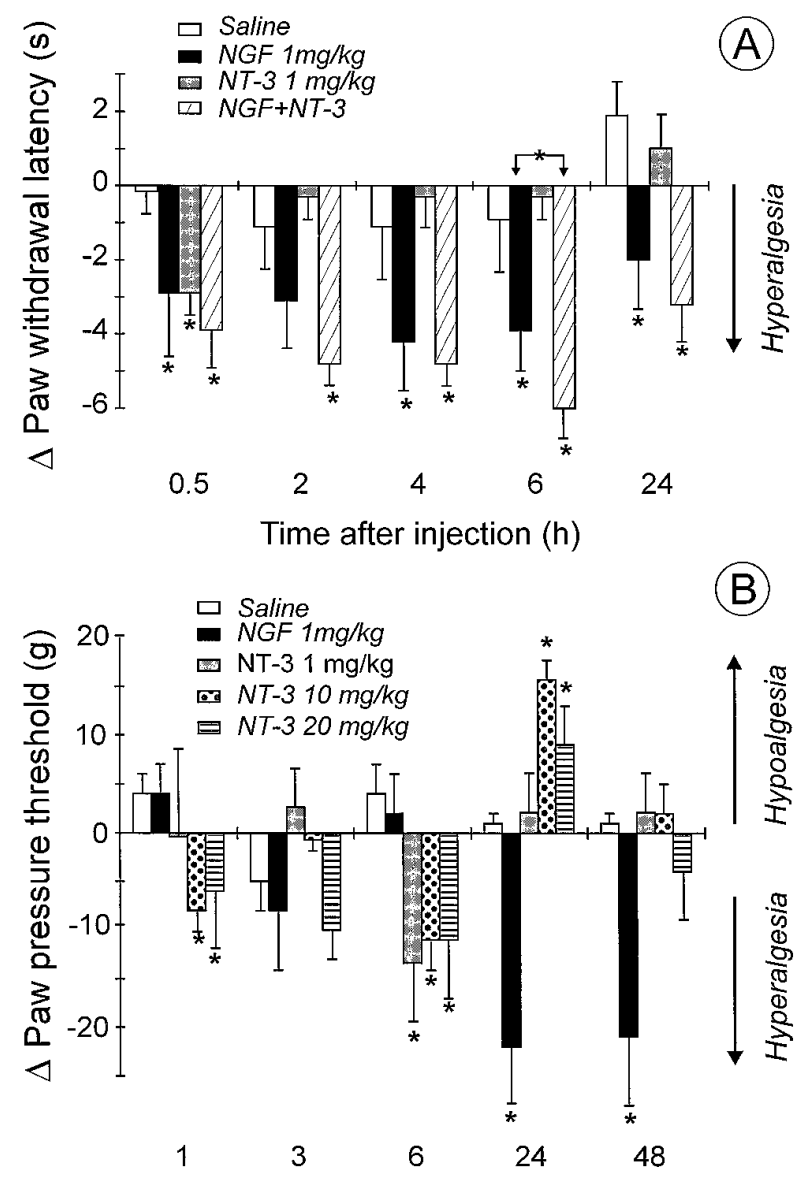

Time after injection (h)

Figure 5. $A$, Effect of a single intraperitoneal administration of saline $(n=6)$, NGF $(n=8)$, or NT-3 separately $(n=9)$ or in combination $(n=$ 9) on rat PWL in the plantar test. NGF and NT-3 were injected immediately after determination of preinjection latencies. Values are mean \pm SEM of PWLs at various intervals after subtraction of preinjection PWLs. * $p<0.05$ versus controls, Mann-Whitney $U$ test. $B$, Effect of single intraperitoneal administration of NGF or NT-3 on the threshold to mechanical stimulation. Saline $(n=5)$, NGF $(n=5)$, and NT-3 at 1 $\mathrm{mg} / \mathrm{kg}(n=5), 10 \mathrm{mg} / \mathrm{kg}(n=10)$, and $20 \mathrm{mg} / \mathrm{kg}(n=5)$ were injected immediately after preinjection threshold values were obtained. Values are mean \pm SEM of paw pressure threshold at various intervals after subtraction of preinjection values. ${ }^{*} p<0.05$ versus controls, Mann-Whitney $U$ test.

co-administration of NGF and NT-3 induced thermal hyperalgesia to the same extent as NGF alone.

The early component of NGF-induced thermal hyperalgesia may be attributed to both activation of the autonomic nervous system (Andreev et al., 1995) and sensitization of peripheral nociceptor terminals (Lewin et al., 1994; Apfel et al., 1995).

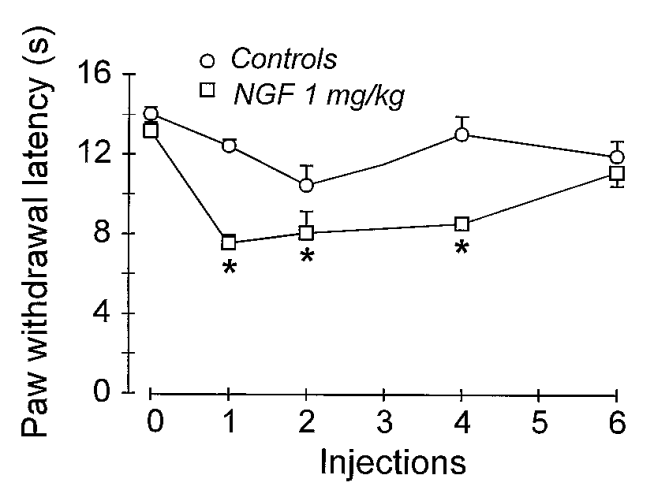

(A)

(B)

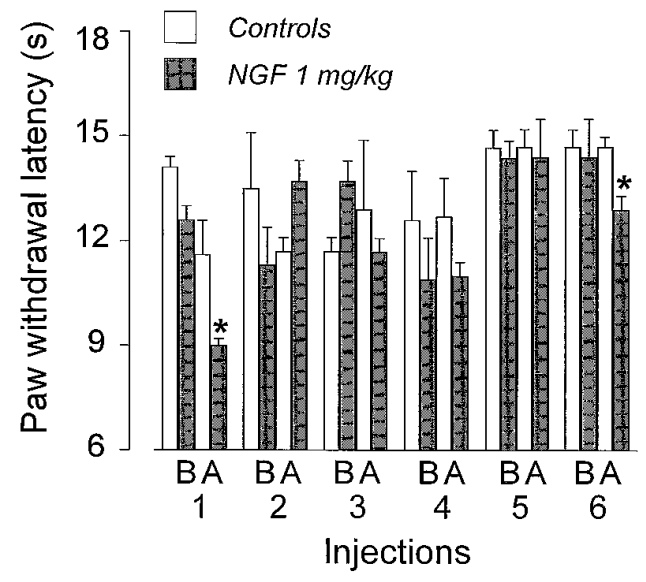

Figure 6. Effect of prolonged administration of saline $(n=6)$ or NGF $(1$ $\mathrm{mg} / \mathrm{kg}$, s.c., 3 times a week for 2 weeks; $n=8$ ) on PWL in the plantar test. $A$, The first dose was injected immediately after preinjection latencies were determined, and PWLs were subsequently determined $1 \mathrm{hr}$ after each of six injections. $B$, PWLs were determined before $(B)$ and $24 \mathrm{hr}$ after $(A)$ each of six injections. ${ }^{*} p<0.05$ versus controls, ANOVA.

Mechanisms responsible for NGF-induced late thermal hyperalgesia appeared to involve the activation of central NMDA receptors for glutamate and peripheral bradykinin $\mathrm{B}_{1}$, but not substance P-neurokinin (SP-NK N $_{1}$ ) receptors (Lewin et al., 1994; Rueff et al., 1996). Thompson et al. (1995) showed that a single systemic injection of NGF in rats induces delayed changes in the nociceptive spinal reflexes, which involve $\mathrm{NK}_{1}$ receptor activation. This was attributed to a possible increase in centrally released SP within hours of NGF administration. However, this supposition is not supported by the present study, in which both thermal and mechanical hyperalgesia reached their maximum 24 hr after NGF administration, when the release of SP-LI from the isolated spinal cord was not different from that from cords of 
saline-treated rats. Furthermore, prolonged administration of NGF to rats has been reported to increase both basal outflow and electrically evoked release of SP-LI from the spinal cord (Malcangio et al., 1997). Surprisingly, this enhanced availability of SP within the spinal cord after NGF treatment did not correspond to a prolonged thermal hyperalgesic effect. By contrast, rats developed tolerance to both early and late components of NGFinduced thermal hyperalgesia. Among the several systems that could account for tolerance to early NGF-induced hyperalgesia, depletion of histamine from mast cells may play a major role. Furthermore, a downregulation of central $\mathrm{NK}_{1}$ receptors attributable to the increased SP levels might have occurred and would explain rat reduced sensitivity to noxious stimulation during NGF treatment. A speculative explanation for NGF-induced tolerance to the late component of its hyperalgesic effect could be that during the treatment, an increase in BDNF expression occurs in the dorsal horn (Priestley et al., 1996). Intrathecally administered BDNF has been reported to induce antinociception (Siuciak et al., 1994) and thus may counteract the pronociceptive effect of NGF. In contrast with our findings, it has been previously reported that daily injection of NGF for $4 \mathrm{~d}$ does not modify the mechanical hyperalgesia induced by the first dose, thus suggesting that there were no cumulative effects, and tolerance did not develop (Lewin et al., 1993). An explanation for this discrepancy may stem from the different protocols used for the prolonged treatment, the administration of human recombinant NGF rather that NGF extracted from mouse salivary glands and, possibly, the fact that thermal rather than mechanical thresholds were monitored.

\section{NT-3 effects on pain threshold and release of SP-LI from the spinal cord}

In contrast to the hyperalgesic action of NGF, a single systemic administration of NT-3 (10 and $20 \mathrm{mg} / \mathrm{kg}$ ) induced a hypoalgesic effect $24 \mathrm{hr}$ after injection after the induction of mechanical hyperalgesia at earlier time points. However, as for NGF, the effect of the nociceptive threshold was not concomitant with changes in evoked release of SP-LI from the spinal cord. The initial mechanical hyperalgesia after NT-3 injection may be attributable to activation of the autonomic system through an action on trkA receptors by a transient high concentration. NT-3 has been recently shown to mediate sympathetic neuron survival through a regulation of trkA receptors (Belliveau et al., 1997). NT-3-induced changes in mechanical threshold are in line with recent work suggesting that tactile sensation is a target for NT-3 (Airaksinen et al., 1996). The doses necessary to detect an antinociceptive effect in this study seem reasonable in view of the finding that $20 \mathrm{mg} / \mathrm{kg} \mathrm{NT}-3$ was necessary to prevent pyridoxineinduced neuropathy (Helgren et al., 1997). The slow onset of the antinociceptive effect of NT-3 may suggest a central effect, which could involve retrograde transport of NT-3 to the DRG after uptake at peripheral terminals. However, it is not yet known whether NT-3 is transported from DRG to the spinal cord.

Prolonged treatment of rats with NT-3, following a protocol identical to that for NGF, although not changing thermal sensitivity, decreased SP-LI release in the spinal cord. Thus, as is the case with NGF, NT-3 effects on thermal nociceptive threshold did not correlate with SP-LI release. A reduction, although not statistically significant, in capsaicin-induced release of SP-LI and CGRP-LI after NT-3 treatment was also observed. However, the total content of both peptides in the spinal cord was not changed. These data indicate that exogenous NT-3 can influence the re- lease of neurotransmitters contained in sensory neurons evoked by electrical stimulation of the dorsal roots but not that evoked by capsaicin. This conclusion is substantiated by the lack of effect of acutely superfused NT-3 on capsaicin-induced release of SP-LI from the spinal cord.

There is evidence in the rat that myelinated fibers, which do not normally contain peptides, retrogradely transport NT-3 (DiStefano et al., 1992). Thus a direct effect of NT-3 on SPcontaining terminals is unlikely unless NT-3 interacts with the trkA receptor on nociceptor terminals (Kashiba et al., 1996).

\section{Effect of spinal cord superfusion with NGF and NT-3 on SP-LI release}

In contrast to NGF, which was ineffective in vitro, NT-3 acutely superfused through spinal cord slices dose-dependently inhibited the evoked release of SP-LI without changing the basal outflow. NT-3-induced inhibition of evoked SP-LI release was not prevented by co-superfusion of NGF. Furthermore, even when evoked SP-LI release was enhanced by 2 weeks of in vivo treatment with NGF, NT-3 was still able to depress significantly the evoked release of the peptide from central terminals of primary afferents. These data indicate that NT-3 can modulate the release of SP-LI under normal conditions as well as under conditions of enhanced release such as after treatment in vivo with NGF. If this treatment with NGF mimicked inflammatory conditions, in which mechanical and thermal hypersensitivity are NGF-dependent, it may have induced expression of SP in myelinated fibers, which do not normally contain this peptide (Neumann et al., 1996). The release of this extra SP would have occurred under our experimental conditions (in which electrical stimulation also recruits myelinated, fast-conducting fibers) and appeared to be inhibited by NT-3. NT-3 has been recently suggested to behave as a rapid modulator of synaptic activity in the CNS (Lohof et al., 1993; Kim et al., 1994), and the present study substantiates this possibility. The observation that the effect of NT-3 was not prevented by an activation of spinal cord trkA receptors by NGF suggests that an activation of the trkC receptor may be responsible for the NT-3 effect, and, indeed, these receptor binding sites have been found in the dorsal horn of the monkey (Ardvisson et al., 1994) and rat (J. V. Priestley, personal communication), although their exact localization still has to be shown. Unfortunately a direct block of trkC receptors is not yet feasible because of lack of pharmacological tools. Thus, in an attempt to functionally block NT-3-induced inhibition of the evoked release of SP-LI, two major systems that inhibit this release have been considered as potential intermediates: $\mathrm{GABA}_{\mathrm{B}}$ ergic and opioid. In this study, naloxone but not CGP 36742 superfusion prevented the effect of NT-3, suggesting that enkephalins contained in dorsal horn neurons may be mediating NT-3-induced inhibition of SP release.

This study suggests that NGF-induced hyperalgesia may be partly attributable to an increased SP synthesis and consequent release in the spinal cord, and that NT-3, either systemically injected or acutely applied to the spinal cord, exerts a direct inhibitory action on SP-LI release from primary afferent central terminals (Table 2). In addition, NT-3 induces antinociception 24 hr after single systemic administration. Assuming that the mechanism for an NT-3 antinociceptive effect is the inhibition of SP release, the neurotrophin would have reached the spinal cord only if retrogradely transported by large fibers. These fibers, once electrically stimulated, could have delivered NT-3 in the vicinity of SP-containing, unmyelinated fiber terminals in the dorsal horn. A possible target for NT-3 appeared the enkephalinergic neurons, 


\begin{tabular}{|c|c|c|c|c|}
\hline Neurotrophin & Treatment & Thermal threshold & Mechanical threshold & $\begin{array}{l}\text { Electrically-evoked } \\
\text { release of SP-LI }\end{array}$ \\
\hline \multicolumn{5}{|l|}{ In vivo } \\
\hline NGF & Single injection & $\downarrow$ & $\downarrow$ & No effect \\
\hline NT-3 & Single injection & No effect & $\downarrow, \uparrow$ & No effect \\
\hline NGF & Prolonged & No effect & $\downarrow *$ & $\uparrow$ \\
\hline NT-3 & Prolonged & No effect & - & $\downarrow$ \\
\hline \multicolumn{5}{|l|}{ In vitro } \\
\hline NGF & $1-100 \mathrm{ng} / \mathrm{ml}$ & - & - & No effect \\
\hline NT-3 & $1-100 \mathrm{ng} / \mathrm{ml}$ & - & - & $\downarrow$ \\
\hline NT-3 + naloxone & $\begin{array}{l}10 \mathrm{ng} / \mathrm{ml}+0.1 \mu \mathrm{M} \\
10 \mathrm{ng} / \mathrm{ml}+100\end{array}$ & - & - & No effect \\
\hline NT-3 + CGP 36742 & $\mu \mathrm{M}$ & - & - & $\downarrow$ \\
\hline
\end{tabular}

the activation of which would have in turn reduced the release of SP. However, although retrograde transport of peripherally derived NT-3 from target tissue to the cell bodies of primary afferent fibers in the DRG is likely to occur, anterograde transport of the neurotrophin from the cell bodies to the central terminals in the spinal cord remains to be shown. Interestingly, anterograde transport of exogenous neurotrophins has been reported in the developing visual system (von Bartheld et al., 1996).

\section{REFERENCES}

Airaksinen MS, Koltzenburg M, Lewin GR, Masu Y, Helbig C, Wolf E, Brem G, Toyka KV, Thoenen H, Meyer M (1996) Specific subtypes of cutaneous mechanoreceptors require neurotrophin-3 following peripheral target innervation. Neuron 16:287-295.

Andreev NY, Dimitrieva N, Koltzenburg M, McMahon SB (1995) Peripheral administration of nerve growth factor in the adult rat produces a thermal hyperalgesia that requires the presence of sympathetic postganglionic neurones. Pain 63:109-115.

Andreeva L, Rang HP (1993) Effect of bradykinin and prostaglandins on the release of CGRP-like immunoreactivity from the rat spinal cord in vitro. Br J Pharmacol 108:185-190.

Apfel SC, Newel M, Dormia C, Kessler JA (1995) Kappa opioid receptors participate in nerve growth factor-induced hyperalgesia. Neuroscience 68:1199-1206.

Ardvisson U, Risling M, Frisen J, Piehl F, Fried K, Hokfelt T, Cullheim S (1994) TrkC-like immunoreactivity in the primate descending serotoninergic system. Eur J Neurosci 6:230-236.

Belliveau DJ, Krivko I, Kohn J, Lachance C, Pozniak C, Rusakov D, Kaplan D, Miller FD (1997) NGF and neurotrophin-3 both activate trkA on sympathetic neurons but differentially regulate survival and neuritogenesis. J Cell Biol 136:375-388.

Dirig DM, Hua X-Y, Yaksh TL (1997) Temperature dependency of basal and evoked release of amino acids and calcitonin gene-related peptide from rat dorsal spinal cord. J Neurosci 17:4406-4414.

DiStefano PS, Friedman B, Radziejewski C, Alexander C, Boland P, Schick CM, Lindsay RM, Wiegand SJ (1992) The neurotrophins BDNF, NT-3, and NGF display distinct patterns of retrograde axonal transport in peripheral and central neurons. Neuron 8:983-993.

Ebendal T (1992) Function and evolution in the NGF family and its receptors. J Neurosci Res 32:461-470.

Ernfors P, Persson H (1991) Developmentally regulated expression of HDNF/NT-3 mRNA in rat spinal cord motor neurones and expression of BDNF mRNA in embryonic dorsal root ganglion. Eur $\mathrm{J}$ Neurosci 3:953-961.

Go VLW, Yaksh TL (1987) Release of substance P from the cat spinal cord. J Physiol (Lond) 391:141-167.

Goedert M, Stoeckel K, Otten U (1981) Biological importance of the retrograde axonal transport of nerve growth factor in sensory neurons. Proc Natl Acad Sci USA 78:5895-5898.

Hargreaves K, Dubner R, Brown F, Flores C, Joris J (1988) A new and sensitive method for measuring thermal nociception in cutaneous hyperalgesia. Pain 32:77-88.
Helgren ME, Cliffer KD, Torrento K, Cavnor C, Curtis R, DiStefano PS, Wiegand SJ, Lindsay RM (1997) Neurotrophin-3 administration attenuates deficits of pyridoxine-induced large-fiber sensory neuropathy. J Neurosci 17:372-382.

Kangrga I, Randic M (1990) Tachykinins and calcitonin gene-related peptide enhance release of endogenous glutamate and aspartate from the rat spinal dorsal horn slice. J Neurosci 10:2026-2038.

Kangrga I, Randic M (1991) Outflow of endogenous aspartate and glutamate from the rat spinal dorsal horn in vitro by activation of low- and high-threshold primary afferent fibers. Modulation by $\mu$-opioids. Brain Res 553:347-352.

Kashiba H, Ueda Y, Senba E (1996) Coexpression of preprotachykinin-A, $\alpha$-calcitonin gene-related peptide, somatostatin, and neurotrophin receptor family messenger RNAs in rat dorsal root ganglion neurons. Neuroscience 70:179-189.

Kerkut GA, Bagust J (1995) The isolated mammalian spinal cord. Prog Neurobiol 46:1-48.

Kim HG, Wang T, Olafsson P, Lu B (1994) Neurotrophin 3 potentiates neuronal activity and inhibits gamma-aminobutyratergic synaptic transmission in cortical neurons. Proc Natl Acad Sci USA 91:12341-12345.

Koliatsos VE, Clatterbuck RE, Winslow JW, Cayouette MH, Price DL (1993) Evidence that BDNF is a trophic factor for motor neurons in vivo. Neuron 10:359-361.

Lewin GR, Ritter AM, Mendell LM (1993) Nerve growth factorinduced hyperalgesia in the neonatal and adult rat. $\mathrm{J}$ Neurosci 13:2136-2148.

Lewin GR, Rueff A, Mendell LM (1994) Peripheral and central mechanisms of NGF-induced hyperalgesia. Eur J Neurosci 6:1903-1912.

Lindsay RM, Shooter EM, Radeke MJ, Misko TP, Dechant G, Thoenen H, Lindholm D (1990) Nerve growth factor regulates expression of the nerve growth factor receptor gene in adult sensory neurons. Eur J Neurosci 2:389-396.

Lohof AM, Ip NY, Poo M (1993) Potentiation of developing neuromuscular synapses by the neurotrophins NT-3 and BDNF. Nature 363:350-353.

Maggi CA (1991) Capsaicin and primary afferent neurons: from basic science to human therapy? J Auton Nerv Syst 33:1-14.

Malcangio M, Bowery NG (1993) Gamma-aminobutyric $\operatorname{acid}_{B}$, but not gamma-aminobutyric $\operatorname{acid}_{\mathrm{A}}$ receptor activation, inhibits electrically evoked substance P-like immunoreactivity release from the rat spinal cord in vitro. J Pharmacol Exp Ther 266:1490-1496.

Malcangio M, Bowery NG (1994) Spinal cord SP release and hyperalgesia in monoarthritic rats: involvement of the $\mathrm{GABA}_{\mathrm{B}}$ receptor system. Br J Pharmacol 113:1561-1566.

Malcangio M, Bowery NG (1996a) GABA and its receptors in the spinal cord. Trends Pharmacol Sci 17:457-462.

Malcangio M, Bowery NG (1996b) Calcitonin gene-related pepide content, basal outflow and electrically-evoked release from monoarthritic rat spinal cord in vitro. Pain 66:351-358.

Malcangio M, Garrett NE, Tomlinson DR (1997) Nerve growth factor treatment increases stimulus-evoked release of sensory neuropeptides in the spinal cord. Eur J Neurosci 9:1101-1104.

Molliver DC, Radeke MJ, Feinstein SC, Snider WD (1995) Presence or absence of TrkA protein distinguishes subsets of small sensory neurons 
with unique cytochemical characteristics and dorsal horn projections. J Comp Neurol 361:404-416.

Neumann S, Doubell TP, Leslie T, Woolf CJ (1996) Inflammatory pain hypersensitivity mediated by phenotypic switch in myelinated primary sensory neurons. Nature 384:360-364.

Priestley JV, Michael GJ, Averill S, Nitkunan A, Wotherspoon G, Rattrav M, Bennett DLH, Yan Q, McMahon SB (1996) NGF treatment increases BDNF expression in trkA immunoreactive dorsal root ganglion cells and in their central terminations within the spinal cord. Soc Neurosci Abstr 22:548.

Rueff A, Dawson AJLR, Mendell LM (1996) Characteristics of nerve growth factor induced hyperalgesia in adult rats: dependence on enhanced bradykinin-1 receptor activity but not neurokinin-1 receptor activation. Pain 66:359-372.

Siuciak JA, Altar CA, Wiegand SJ, Lindsay RM (1994) Antinociceptive effect of brain-derived neurotrophic factor and neurotrophin-3. Brain Res 633:326-330.

Teoh H, Malcangio M, Fowler LJ, Bowery NG (1996) Evidence for release of glutamic acid, aspartic acid and substance $\mathrm{P}$ but not $\gamma$-amino butyric acid from primary afferent fibres in rat spinal cord. Eur J Pharmacol 302:27-36.

Thompson SWN, Dray A, McCarson KE, Krause JE, Urban L (1995) Nerve growth factor induces mechanical allodynia associated with novel A fibre-evoked spinal reflex activity and enhanced neurokinin-1 receptor activation in the rat. Pain 62:219-231.

von Bartheld CS, Byers MR, Williams R, Bothwell M (1996) Anterograde transport of neurotrophins and axodendritic transfer in the developing visual system. Nature 379:830-833.

Zhou X-F, Rush RA (1994) Localization of neurotrophin-3-like immunoreactivity in the rat central nervous system. Brain Res 643:162-172. 